\title{
Element Content of Crested Wheatgrass Grown on Reclaimed Coal Spoils and on Soils
} Nearby

\author{
JAMES A ERDMAN AND RICHARD J. EBENS
}

\section{Abstract}

Fairway crested wheatgrass [Agropyron cristatum (L.) Gaertn.] was analyzed to determine the possible effects of coal spoils at the Dave Johnston Mine, Wyoming, on the chemical composition of this widely used reclamation species. Concentrations of 8 of the 26 elements tested by analysis of variance showed significant differences between the samples growing in $10-15 \mathrm{~cm}$ of topsoil covering the spoils and samples from soils nearby. Samples from the mined areas showed about 50\% higher concentrations. Concentrations of manganese and uranium, however, were about 150 and $200 \%$ higher, respectively. Concentrations of the trace elements cobalt, manganese, and zinc-essential in animal nutrition-ranged from deficient levels in "control" samples to adequate or marginal levels in samples from reclaimed spoils. The phosphorus content of grasses that grew on spoil material was two-thirds that of the control grasses, to the point where the former may be nutritionally deficient as a cattle forage.

Crested wheatgrass was sampled at the Dave Johnston mine at the southern edge of the Powder River Basin in Wyoming as part of a larger study designed to assess the effects of reclaimed spoils on the element concentrations in vegetation from eight surface coal mines in the Northern Great Plains (Erdman and Ebens 1975). This species of wheatgrass dominates the revegetated spoil banks at the Dave Johnston Mine, as it does at many of the surface mines that were sampled.

The Dave Johnston Mine is located about $24 \mathrm{~km}$ northeast of Glenrock, in Converse County, site of Pacific Power and Light Company's Dave Johnston powerplant.

Crested wheatgrass is used both as a forage for cattle (Blincoe and Lambert 1972) and for land reclamation (Bauer et al. 1976). It is used more widely for reseeding purposes than any other grass, and has been recommended for reseeding depleted rangelands in semiarid regions (Sotola 1940). Along with bromegrass, it has been a widely used cultivated grass in the Canadian Prairies (Heinrichs and Carson 1956). Its nutritional value and palatability are high when the plant is green and succulent, but decrease as it becomes mature (Sotola 1940; Pingrey and Dortignac 1959). This cool-season grass apparently does not retain its forage value through the summer grazing season as do many of the native warm-season grasses (Heinrichs and Carson 1956). For this reason optimum utilization of such pasturage might require rotational grazing.

The authors are botanist and geologist, respectively, U.S. Geological Survey, Denver, Colorado 80225

Authors thank W. Cary, T.F. Harms, M.J. Malcolm, and C.S.E. Papp, who performed the chemical analyses at the Denver Laboratories of the U.S. Geological Survey. Approval to sample at the mine was granted by James Sarvey, Pacific Power and Light Company. Manuscript received March 9, 1978.

\section{Methods}

Sampling was conducted on July 24,1974 , when growth of wheatgrass was at the mature seed stage of development. A three-level analysis of variance design was used. The purpose of the first level was to assess differences in element concentrations between crested wheatgrass growing on spoil materials and on soils native to the site (topsoil borrow). The second level was included to estimate the degree of uniformity in the element contents of wheatgrass within the two substrate types. A third level, based on the analyses of duplicates or splits of each sample, was included to estimate the laboratory precision (reproducibility). This precision was satisfactory for all elements but mercury, so the variability observed in the data was, for the most part, natural.

Ten samples were collected at randomly selected locations within two tracts of reclaimed spoil piles. Two of these locations were within a 19-ha tract that had been seeded in autumn 1969 with a seed mixture that included standard crested wheatgrass [Agropyron desertorum (Fisch.) Schult]. The remaining eight locations were within a 45-ha tract seeded in autumn 1972. The seed mixture in this latter tract included Fairway crested wheatgrass [A. cristatum (L.) Gaertn]. Both tracts had been covered with $10-15 \mathrm{~cm}$ of topsoil prior to seeding, but the kind of surface material at the sampling locations varied considerably, ranging from spoil material (mixed overburden and coal) to as much as $15 \mathrm{~cm}$ of topsoil.

The predominant soils in the area are mapped (U.S. Soil Conservation Service 1970) as Haplargids, used mostly for range and some irrigated crops.

The only sites available for collecting control samples of crested wheatgrass were two topsoil borrow areas adjoining the active mine. The upper $10-15 \mathrm{~cm}$ of topsoil and vegetation had been removed with self-loading scrapers and spread over the reshaped spoils. One of the areas, 12 ha, was seeded in spring 1972; the other area, 28 ha, was seeded in autumn of the same year. Both borrow areas were seeded with Fairway crested wheatgrass. The concentrations of elements observed in these borrow-area samples were generally close to the concentrations found in crested wheatgrass growing in native soils in western North Dakota (unpublished data).

We clipped the mature grass samples about $15 \mathrm{~cm}$ above the ground surface in order to minimize soil contamination. Samples were then placed in cloth bags, taken to the U.S. Gcological Survey laboratories, and pulverized in a Wiley mill. The resulting homogenized material was divided into two equal portions. The number of samples for this study was therefore doubled from 20 field samples to 40 laboratory samples. These 40 samples were then placed in a randomized sequence, thereby transforming any systematic laboratory error that may be present into a random error.

A weighed portion of each sample was burned to ash in a muffle furnace in which the heat was increased $50^{\circ} \mathrm{C}$ per hour to a temperature of $550^{\circ} \mathrm{C}$ and held at this temperature for 14 hours. The resulting ash was then weighed to determine the ash yield. Weighed aliquots of the samples were wet ashed, according to methods described by Harms and Papp (1975), in order to determine the 
concentrations of those elements tnat would be volatilized and lost by burning.

Methods of analysis used for these volatile elements were atomic absorption spectrophotometry for antimony and arsenic, a turbidimetric method for total sulfur, flameless atomic absorption for mercury, a fluorimetric method for selenium, and a selective ion electrode method for fluorine. The methods of analysis and the elements determined in the ash were: atomic absorption-cadmium, calcium, cobalt, lithium, potassium, silicon, sodium, and zinc; colorimetry-phosphorus; and fluorimetry-uranium. The remaining elements reported were analyzed by emission spectrography.

When concentrations of some elements (cobalt, molybdenum, uranium, and vanadium) fell below the limits of detection, means were estimated by techniques developed by Cohen (1959) and described for geochemical applications by Miesch (1967). Because the analysis of variance requires a completely numerical data set, we arbitrarily assigned values equal to 0.7 of the lower limit of detection of a given element to samples whose concentrations were too low to be measured.

We transformed the concentrations of all elements to logarithms because their frequency distributions tend to be more nearly symmetrical on a logarithmic scale than on an arithmetic scale. The geometric mean was used to estimate the most typical concentration and is convenient for comparing the element content of the samples of crested wheatgrass taken from the two type of substrate.

\section{Results and Discussion}

Of 26 elements tested by analysis of variance eight showed significant differences in concentrations between the two areas (Table 1). Concentrations of cadmium, cobalt, fluorine, manganese, uranium, vanadium, and zinc in samples that grew on spoils ranged from about $30-200 \%$ higher than those grown in the borrow areas. Conversely, the phosphorus content in

Table 1. Geometric mean concentrations and observed ranges of elements in crested wheatgrass from topsoil borrow areas and from reclaimed spoil areas.

\begin{tabular}{|c|c|c|c|c|}
\hline \multirow[b]{2}{*}{ Element } & \multicolumn{2}{|c|}{ Topsoil borrow areas } & \multicolumn{2}{|c|}{ Reclaimed spoil areas } \\
\hline & Mean & Range & Mean & Range \\
\hline $\mathrm{Al}, \%$ & 0.069 & $0.030-.27$ & 0.11 & $0.041-.37$ \\
\hline $\mathrm{B}, \mathrm{ppm}$ & 15 & $11-28$ & 17 & $11-48$ \\
\hline $\mathrm{Ba}, \mathrm{ppm}$ & 12 & $6-22$ & 10 & $6-22$ \\
\hline $\mathrm{Ca}, \%$ & .26 & $.22-.30$ & .23 & $.16-.35$ \\
\hline${ }^{2} \mathrm{Cd}, \mathrm{ppm}$ & .054 & $.016-15$ & .082 & $.034-.15$ \\
\hline $\mathrm{Co}, \mathrm{ppm}$ & .069 & $<.054 .13$ & .099 & $<.058-.44$ \\
\hline $\mathrm{Cr}, \mathrm{ppm}$ & .27 & $.11-.60$ & .40 & $.16-1.1$ \\
\hline $\mathrm{Cu}, \mathrm{ppm}$ & 2.8 & $1.6-6.0$ & 3.2 & $1.6-5.9$ \\
\hline${ }^{2} \mathrm{~F}, \mathrm{ppm}$ & 4.5 & 3-6 & 6.2 & 3-10 \\
\hline $\mathrm{Fe}, \mathrm{ppm}$ & 190 & $81-350$ & 270 & $120-740$ \\
\hline $\mathrm{Hg}, \mathrm{ppm}$ & .011 & $.01-.02$ & .011 & $.01-.02$ \\
\hline $\mathrm{K}, \%$ & 1.1 & $.90-1.4$ & 1.2 & $.72-1.6$ \\
\hline Li,ppm & .82 & $.29-1.8$ & 1.3 & $.58-4.0$ \\
\hline $\mathrm{Mg}, \%$ & .12 & $.08-.17$ & .11 & $.08-.17$ \\
\hline${ }^{3} \mathrm{Mn}, \mathrm{ppm}$ & 16 & $5.6-36$ & 39 & $23-140$ \\
\hline Mo, ppm & .39 & $<.38-.58$ & .43 & $<.39-.84$ \\
\hline $\mathrm{Na}, \mathrm{ppm}$ & 8.4 & $3.6-22$ & $11^{.43}$ & $3.5-21$ \\
\hline${ }^{3} \mathrm{P}, \%$ & .13 & $.09-.19$ & .084 & $.041-.17$ \\
\hline S, total, \% & .17 & $.10-.27$ & .18 & $.09-.33$ \\
\hline Se, ppm & .23 & $.10-.60$ & .27 & $.10-.70$ \\
\hline $\mathrm{Si}, \%$ & 1.2 & $.7-1.9$ & .98 & $.44-1.9$ \\
\hline Sr, ppm & 25 & $16-39$ & $25^{.90}$ & $14-41$ \\
\hline $\mathrm{Ti}, \mathrm{ppm}$ & 16 & $3-50$ & 26 & $11-74$ \\
\hline${ }^{2} \mathrm{U}, \mathrm{ppm}$ & .021 & $<0.21-.067$ & .062 & $<.028-.55$ \\
\hline${ }^{-} \mathrm{V}, \mathrm{ppm}$ & .63 & $<.54-.98$ & .82 & $<.69-1.5$ \\
\hline $\mathrm{Zn}, \mathrm{ppm}$ & $20^{.00}$ & $13-28$ & $26^{.02}$ & $18-32$ \\
\hline
\end{tabular}

${ }^{1}$ Data are based on 10 samples and their analytical duplicates from each area; concentralions are expressed on a dry basis.

Means are significantly different at the $P<0.05$ level.

Means are significantly different at the $P<0.01$ level. samples from the spoil tracts was about two-thirds that in the samples collected from the control areas.

Two elements of environmental concern, but for which only very limited data are available, are antimony and arsenic. Their detection ratios (that is, the ratio of the number of samples in which the element was detected to the total number of samples analyzed) and ranges in dry matter follow: antimony, 0:40 $<0.05 \mathrm{ppm}$; arsenic in wheatgrass from the topsoil borrow areas, $1: 20,<0.05-0.05 \mathrm{ppm}$, and in wheatgrass from the reclaimed spoil areas, 10:20,<0.05-0.09 ppm. Arsenic appears to be higher in samples from the spoil, judged by the differences in detection ratios.

It is clear from these results that reclaimed spoils can affect the element composition of crested wheatgrass to a measurable degree. The next and more difficult problem is to assess these differences as they might bear on productive post-mining land use. How will these geochemical alterations affect the nutritional requirements of range plants or of livestock that utilize the forage?

Possible deficiencies in elements essential to vegetation have attracted a major interest in mine-spoil reclamation efforts. The most notable element is phosphorus. Our analyses for phosphorus in crested wheatgrass confirm the conclusions of Sandoval et al. (1973) that the available phosphorus in spoil materials derived from the Fort Union Formation is generally very low (Table 1), and is the most pronounced fertility limitation to successful revegetation of reclaimed spoil banks. The fact that wheatgrass is reasonably well established at the Dave Johnston Mine, however, is evidence that this is not a severe limitation to land reclamation.

The potential deficiency of phosphorus for cattle production, however, may be of some importance. Minimum phosphorus requirements of range cattle vary to a degree, but a recommended dietary level of $0.13 \%$ has appeared quite consistently in the literature (Whitman et al. 1951). Recent estimates are considerably higher (see, for example Church et al. 1971). Whereas the phosphorus content of wheatgrass that we sampled from the borrow areas may have been marginal for cattle, the phosphorus concentrations in the grasses from the reclaimed spoils are clearly lower. Whitman et al. (1951) state, however, that phosphorus deficiencies even in native grasses on normal range often occur before the end of the summer season and certainly by early autumn. Other workers concur that pasture and range forage are commonly deficient in phosphorus (Church et al. 1971; Knox and Watkins 1958). The $0.084 \%$ level for phosphorus given in Table 1 is not unusual in crested wheatgrass. It is similar to those levels reported for crested wheatgrass from Canada (Heinrichs and Carson 1956) and is identical to the average of 13 samples collected from the western United States over the past several years (unpublished data, U.S. Geological Survey). On the other hand, phosphorus levels reported by Sotola (1940) are more similar to those in the samples from the borrow areas. Moreover the optimum calcium-to-phosphorus ratio of 2:1 (Heinrichs and Carson 1956) is closely approximated in the latter samples. Phosphorus supplements, such as bone meal, are commonly provided in range cattle operations (Knox and Watkins 1958) and should be considered in livestock production on reclaimed coal lands.

The problem of potentially toxic elements is a more difficult one. The slight but significantly higher concentrations of cobalt and zinc in the spoil-associated wheatgrass may be of little consequence, because most problems associated with these clements have involved deficiency diseases in livestock (Lee 1975). 
Judging from results reported by Blincoe and Lamber (1972), the cobalt and zinc levels in wheatgrass from the Dave Johnston Mine area are not abnormally high. In fact, zinc may be marginal for livestock production. Probable dietary requirements for these elements are 0.1 and $30-40+$ ppm, respectively (Church et al. 1971). Cobalt levels in Standard crested wheatgrass from northeastern Nevada are reported to be ten to one hundred times greater than those given here (Lambert and Blincoe 1971).

The concentrations of manganese are similar to those reported by Blincoe and Lambert (1972). The probable dietary requirement. for this essential trace element is $20 \mathrm{ppm}$ (Church ct al. 1971).

Significantly higher concentrations of cadmium and fluorine are also noted for those samples that grew on spoils. There is some indication that acid spoils promote fluoride uptake in plants (National Research Council 1974). The average pH of 6.2 for the spoils that we sampled (Erdman et al. 1978) is lower than the pHof 7.2 which is typical of the surface horizon soils of the Powder River Basin (Tidball 1975). The toxicity of fluorine to livestock is well known; chronic fluorosis in grazing animals has occurred widely throughout the world. However, the fluorine concentrations in all samples of crested wheatgrass from the Dave Johnston Mine are well below levels at which normal performance in livestock may be affected (Churct et al. 1971); natural forage normally contains $2-20 \mathrm{ppm}$ fluorine on a dry-weight basis (Gough and Shacklette 1976). The cadmium concentrations are also within the ranges found in other native plants (Connor and Shacklette 1975).

We have found no evidence in the literature that vanadium concentrations pose any problems. Vanadium is relatively nontoxic to animals (Gough and Shacklette 1976).

As for uranium, we know of no recognized critical levels in forage, even though this element is radioactive and can be highly toxic (Sax et al. 1951). It should be noted that higher than normal performance in livestock may be affected (Church et al. clover and alfalfa from these spoils (unpublished data of the authors), as well as in the wheatgrass.

\section{Literature Cited}

Bauer, A., G.W. Gee, and J.E. Gilley 1976. Physical, chemical and biological aspects of reclamation of strip-mined lands in western North Dakota, final report. North Dakota Agr. Exp. Sta. 605 p.

Blincoe, C., and T.L. Lambert 1972. Micronutrient trace element composition of crested wheatgrass. J. Range Manage. 25:128-130.

Church, D.C., G.E. Smith, J.P. Fontenot, and A.T. Rallston 1971. Digestive Physiology and Nutrition of Ruminants, vol. 2-Nutrition. Oregon State Univ.
Cohen, A.C., Jr. 1959. Simplified estimators for the normal distribution when samples are singly censored or truncated. Technometrics. 1:217-237.

Connor, J.J., and H.T. Shacklette 1975. Background geochemistry of some rocks, soils, plants and vegetables in the conterminous United States. U.S. Geol. Survey Prof. Paper 574-F. $168 \mathrm{p}$.

Erdman, J.A., and R.J. Ebens. 1975. A variance analysis of the element composition of sweetclover and associated spoil materials from selected coal mines in the Northern Great Plains. In: Geochemical survey of the western coal regions, 2nd annual progress report (July, 1975). U.S. Geol. Survey Open-file Rep. No. 75-436. 29-35.

Erdman, J.A., R.J. Ebens, and A.A. Case. 1978. Molybdenosis: a potential problem in ruminants grazing on coal-mine spoils. J. Range Manage. 31:3436.

Gough, L.P., and H.T. Shacklette. 1976. Toxicity of selected elements to plants, animals, and man-an outline. U.S Geol. Survey Open-file Rep. No. 76-746. $46 \mathrm{p}$.

Harms, T.F., and C.S.E. Papp. 1975. Analysis of plants or plant ash by methods other than emission spectroscopy. In: Geochemical survey of the western coal regions, 2nd annual progress report (July, 1975). U.S. Geol Survey Open-file Rep. No. 75-436. 74-79.

Heinrichs, D.H., and R.B. Carson. 1956. Chemical composition of nine grasses at six stages of development. Canadian J. Agr. Sci. 36:95-106.

Knox, J.H., and W.E. Watkins. 1958. Supplements for range cows. New Mexico Agr. Exp. Sta. Bull. 425. 9 p.

Lambert, T.L., and C. Blincoe. 1971. High concentration of cobalt in wheat grasses. J. Sci. Fd. Agr. 22:8-9.

Lee, H.J. 1975. Trace elements in animal production. In: D.J.D. Nicholas, and A.R. Egan, (eds.) Trace Elements in Soil-plant-animal Systems. Academic, New York. 417 p.

Miesch. A.T. 1967. Methods of computation for estimating geochemical abundance. U.S. Geol. Survey Prof. Paper 574-B. 15 p.

National Research Council. 1974. Effects of fluorides in animals. Nat. Acad. of Sci., Nat. Res. Counc., Comm. on Anim. Nutr., Subcomm. on Fluorosis. Washington, D.C. 70 p.

Pingrey, H.B., and E.J. Dortignac. 1959. Economic evaluation of seeding crested wheatgrass on northern New Mexico rangeland. New Mexico Agr. Exp. Sta. Bull. 433.80 p.

Sandoval, F.J., J.J. Bond, J.F. Power, and W.O. Willis. 1973. Lignite mine spoils in the northern Great Plains-characteristics and potential for reclamation. North Dakota Geol. Survey Educ. Ser. 5. 1-24.

Sax, N.I., M.J. O'Herin, and W.W. Schultz. 1951. Handbook of Dangerous Materials Reinhold, New York.

Sotola, J. 1940. The chemical composition and apparent digestibility of nutrients in crested wheatgrass harvested in three stages of maturity. J. Agr. Res. 61:303-311.

Tidball, R.R. 1975. Sampling requirements for mapping soil geochemistry in the Powder River Basin, Montana-Wyoming. In: Geochemical survey of the western coal regions, 2nd annual progress report (July, 1975). U.S. Geol. Survey Open-file Rep. No. 75-436.20-28.

U.S. Soil Conservation Service. 1970. Distribution of principal kinds of soils: Orders, Suborders, and Great Groups. In: National atlas of the United States of America. U.S. Geol. Survey, sheet 86. 2 p.

Whitman, W.C., D.W. Bolin, E.J. Klosterman, H.J. Klostermann, K.D. Ford, L. Moomaw, D.G. Hoag, and M.L. Buchanan. 1951. Carotene, protein, and phosphorus in rangeland tame grasses of western North Dakota North Dakota Agr. Exp. Sta. Bull. 370. 43 p. 